\title{
How Google's New Algorithm, Hummingbird, Promotes Content and Inbound Marketing
}

\section{Chauntelle Ong Yi Lin, Rashad Yazdanifard}

BS Marketing, Center of Southern New Hampshire (SNHU), HELP College of Arts and Technology (HELP CAT), Kuala Lumpur, Malaysia.

Email:scarlvelt@gmail.com, rashadyazdanifard@yahoo.com

Received December $4^{\text {th }}, 2013$; revised January $4^{\text {th }}, 2014$; accepted January $11^{\text {th }}, 2014$

Copyright (C) 2014 Chauntelle Ong Yi Lin, Rashad Yazdanifard. This is an open access article distributed under the Creative Commons Attribution License, which permits unrestricted use, distribution, and reproduction in any medium, provided the original work is properly cited. In accordance of the Creative Commons Attribution License all Copyrights (C) 2014 are reserved for SCIRP and the owner of the intellectual property Chauntelle Ong Yi Lin, Rashad Yazdanifard. All Copyright ( 2014 are guarded by law and by SCIRP as a guardian.

\section{ABSTRACT}

Marketing is part of our daily lives; however, it has become much more sophisticated. With the advanced technology, nowadays Internet marketing is one of the most powerful marketing channels. Google has recently come up with a new algorithm, hummingbird, for all search results. It is designed more precisely to provide faster query results. This will promote both content and inbound marketing. In this essay, I will expound Google's role in Internet marketing and how it promotes both content and inbound marketing.

\section{KEYWORDS}

\section{New Algorithm; Hummingbird; Content Marketing; Inbound Marketing}

\section{Introduction}

In pace with the progression of economy growth, we had reached a common understanding that marketing trends and activities had undergone vast changes since the past decades to cater to consumers' behaviors and buying patterns. Globalization is one of the major reasons for the improved economy and advanced technology today. The inventions of new technology hence marked the start of the digital revolution, which then brought the onset of the information age.

Balasubramanian, Peterson \& Jarvenpaa [1] explained that mobile commerce often viewed as an extension of ecommerce, is regarded as a distinct channel that conveys ubiquitous value by providing convenience and accessibility at any time and in any place.

With the emergence of $\mathrm{m}$-commerce to e-commerce in our lives, consumers are more dependent on online sources to gain information of the products they want to buy. Hence, it is important that business firms provide a useful content of their products in order to attract customers.

According to Awad \& Ragowsky [2-5], many scholars agree that consumer trust is one of the key factors in- fluencing various desirable outcomes for Internet stores, such as a positive influence on intentions to purchase actual buying decisions, and intentions to reuse e-services.

According to Kim \& Benbasat [6], it is worth examining the factors that have the potential to increase such trust. One of the ways to increase consumer trust in the context of B2C ecommerce is to provide trust-assuring arguments, which are "statements of a claim and its supporting statements used in an Internet store to address trust-related concerns”. The effects of trust-assuring arguments on consumer trust were examined from several aspects, such as the content and the source of a trustassuring argument. With these facts in mind, the purpose of this study is to find out the significance of Internet marketing to consumers, how Google Hummingbird is establishing as a new market, why content marketing and inbound marketing are both important for business companies and marketers and consumers.

\section{Google}

PR Newswire [7] noted that the search engine owns more than two-thirds of the market share. Therefore, no Inter- 
net marketing company can discount the power of Google, specifically when new algorithms are announced. These algorithms refer to what Google, Yahoo, Bing or other search engines use to sort through the billions of websites on the Internet to return the best results to first page, if not the first search result.

According to researches and statistics online, Google is the world's most popular search engine. When it comes to searching for information online, it is no doubt that Google would be the first choice appearing in users' mind.

Google has a number of competitive advantages. Matthews [8] explained that one of the competitive advantages that Google boasts is all of its innovation services. While the case lists 40 different Google services, a Wikipedia article lists well of 100 Google services including the renown "Google Search", Gmail, Blogger, Google Finance, Google Docs, Google Apps, Adsense, and Google Chrome, just to mention a few. While many of these services were developed in-house, Google has also greatly expanded its services through acquisitions, with YouTube, being a classic example.

While there are so many services that is offered by Google, whichever website that we visit will eventually link its way back to Google. Hence, it is remaining as one of the top first choices search engine.

In discussing the incredible value of Google's services, Matthews [8] claims that it lies in the fact that Google can offer nearly all of their services at zero cost to web users. Because of the number of services and users, Google is able to offer an attractive advertising model and make billions of dollars every year. Because of its infrastructure, Google is able to offer an incredible range of services. Google gives its users the chance to enjoy a "one-stop-shop" for all their Internet and computing needs. This is a hard advantage for competitors to overcome; however, Google must continue to innovate in order to make this advantage sustainable.

\subsection{Google Hummingbird}

According to Henshaw [9], claimed that Google's recent September 2013 algorithm update was a major overhaul of the search engine and focuses on creating a more "semantic web" which understands user search "intent" more than prior. With the advent of greater voice based searches being conducted, this essentially creates a much smarter search engine which can decipher intent to a greater degree and return results which are more in line with user intent. As noted by Jumpfactor [10], its analysis indicated that the seo content marketing methodology of today will need to shift even more towards complete user focused writing while minimizing "gaming" tactics or "seo keyword" tactics, which so many SEO firms employ today.

Adding on, Henshaw [9], in September, 2013, Google announced the biggest update to its search engine in over a decade, which it named Hummingbird. Henshaw [9] stressed that the search algorithm is the heart of the search engine. It analyzes and makes sense of billions of pages in order to provide the most relevant search results. The update included a major rewrite of Google's entire algorithm, affecting more than $90 \%$ of search results.

\subsection{What Do You Need to Know about Hummingbird?}

According to Henshaw [9], nothing about your fundamental content strategies need to change, but that some of your tactics will be more important than others concludes that Hummingbird presents the opportunity to create content that is more focused on a searcher's true intent. Writing less ambiguous copy, using synonyms and when relevant, including structured data, may give your content the edge it needs to outperform your competition.

\subsection{How Does the New Algorithm affect Businesses?}

With the fact that Hummingbird presents the opportunity to create content that is more focused on a searcher's true intent, websites, pages or blogs of businesses should contain more liable and related content that the searchers are looking for.

Hence, it is clearly to see that Google Hummingbird is emphasizing the content for searchers and this promotes content marketing.

As explained by Laurel [11] from a business perspective, the algorithm change makes it more important than ever for businesses to ensure both Google, and more importantly, their potential clients, can reach every page on their website through mobile devices. Being world's most popular and the first web search engine introducing the new algorithm, searchers are bound to use Google as their most prior choice of channel for web searching.

In addition, when this new algorithm has been announced, Rautenbach [12] predicted Internet users would have flocked to the web to find out more about how Google's new algorithm update affects them.

According to Aspinall [13], head of content at B2B Marketing said: "Along with social media, perhaps even as a consequence of its assent, content marketing is the B2B marketing world's concept du jour. The wisdom of the central concepts behind inbound marketing techniques goes largely unchallenged, and brands across the world are rushing to reap the rewards of its successful adoption promises. This research reveals that marketers are fully signed up to a content-focused future.

\section{Content Marketing}

The change of Internet use for information is drastic and 
this had a deep impact on Internet marketing too. People are much more marketing-smart now and are more skeptical towards the information they receive. They know what sources of information are accountable for and are not blinded by the advertisements. Rather than the brands or packaging of what businesses and companies have to offer, the consumers are more concerned and interested with the insights or content.

According to Content Marketing Institute [14], consumers have shut down the old-fashioned domain of marketing. They possess their own DVRs to avoid television advertising, often overlook magazine advertising, and now have become so skillful at online surfing that they can take in online information giving any attention to banners or buttons. Content Marketing Institute [14] defined content marketing as a marketing technique of creating and distributing relevant and valuable content to attract, acquire, and engage a clearly defined and understood target audience, with the objective of driving profitable customer action.

On the whole, the purpose of content marketing is to draw the attention of customers and build a long-term and fruitful relationship with the customers to create customer loyalty. With the aim of that, marketers or business firms have to constantly come up with new innovations or ideas that are appropriate and liable. The key is to be able to create a competitive strategy to alter the market values of consumers.

According to Content Marketing Institute [14], content marketing is being used by some of the greatest marketing organizations in the world, including P\&G, Microsoft, Cisco Systems and John Deere. With better understanding of the importance of mobile content strategy, it is important that every aspects of businesses focus on content marketing (Figure 1).

\section{Effect of Content Marketing to Marketers}

According to the DeMers [15], one of the main ways that companies are establishing authority and gaining trust with consumers is consistently creating valuable content through a variety of channels. This typically involves relevant industry information that provides insight or entertainment to an audience. Doing so allows a company to steadily build rapport with its demographic and develop a loyal following.

Pulizzi [16] stated that content marketing remains a top priority for marketers going into 2013: 9 out of 10 marketers are using content marketing which was just as we have seen in the previous two years.

Content Marketing Institute [14] indicated that content marketing is the art of communicating with your customers and prospects without selling. It is non-interruption marketing. Content Marketing Institute [14] stated that instead of pitching products or services, businesses are delivering information that makes their buyers more intelligent. The essence of this content strategy is the belief that if businesses deliver consistent, ongoing valuable information to buyers, they ultimately reward businesses with their business and loyalty.

\section{Social Media Marketing}

Social media and social networking has also contributed to the increase of Internet use and nowadays, more older people are active online. Everyone wants to stay connected and keep news up-to-date. Hence, social networking is driving the usage of mobile, which will promote digital content marketing, inbound marketing and other Internet marketing channels. Another factor towards increase in mobile usage is the innovation of postPC products like tablets, iPads and smart phones. People no longer have to rely only on PCs for access to Internet or social use.

According to Brenner [17], now social media networks and mobile Internet access are making content the hot new thing in marketing. Content our customers want. Content our customers can consume whenever and wherever they want. Brenner [17] predicted the future of marketing that the truly "social business" will use all of its employee resources to communicate with buyers, customers, partners and potential future employees (Figure 2).

\section{Inbound Marketing}

According to Caragher [19], inbound marketing is about creating and sharing content. It is a marketing methodology that focuses on getting found by prospects through blogs, podcasts, eBooks, eNewsletters, website pages, whitepapers, search engine optimization, social media marketing, and other forms of content marketing. By creating content specifically designed to appeal to your ideal clients, inbound marketing attracts qualified prospects to your firm and keeps them coming back for more.

All marketing channels are paid media. SEO requires tremendous effort. Kim [20] claimed that thousands of new websites are launched every day, but the first page of the search results isn't getting any bigger. In fact, if we look at the trends in mobile search, the SERP is getting smaller. That means the competition to get on the first page of Google is getting exponentially greater all the time. Caragher [19] stated that 71 percent of business-to-business (B2B) buyers get their information from the Internet. Caragher [19] also stated that when prospects are looking for the services of what any firm provides, the inbound marketing methodology can help them find the firm. In addition to finding the firm, they must be able to locate the information they are seeking. It's all 


\section{THE STATE OF B2B CONTENT MARKETING 2013}

B2B MARKETING'S 2013 CONTENT MARKETING BENCHMARKING REPORT SUGGESTS CONTENT/INBOUND MARKETING IS MUCH MORE THAN A PASSING TREND. THOUGH PROBLEMS DO PERSIST..

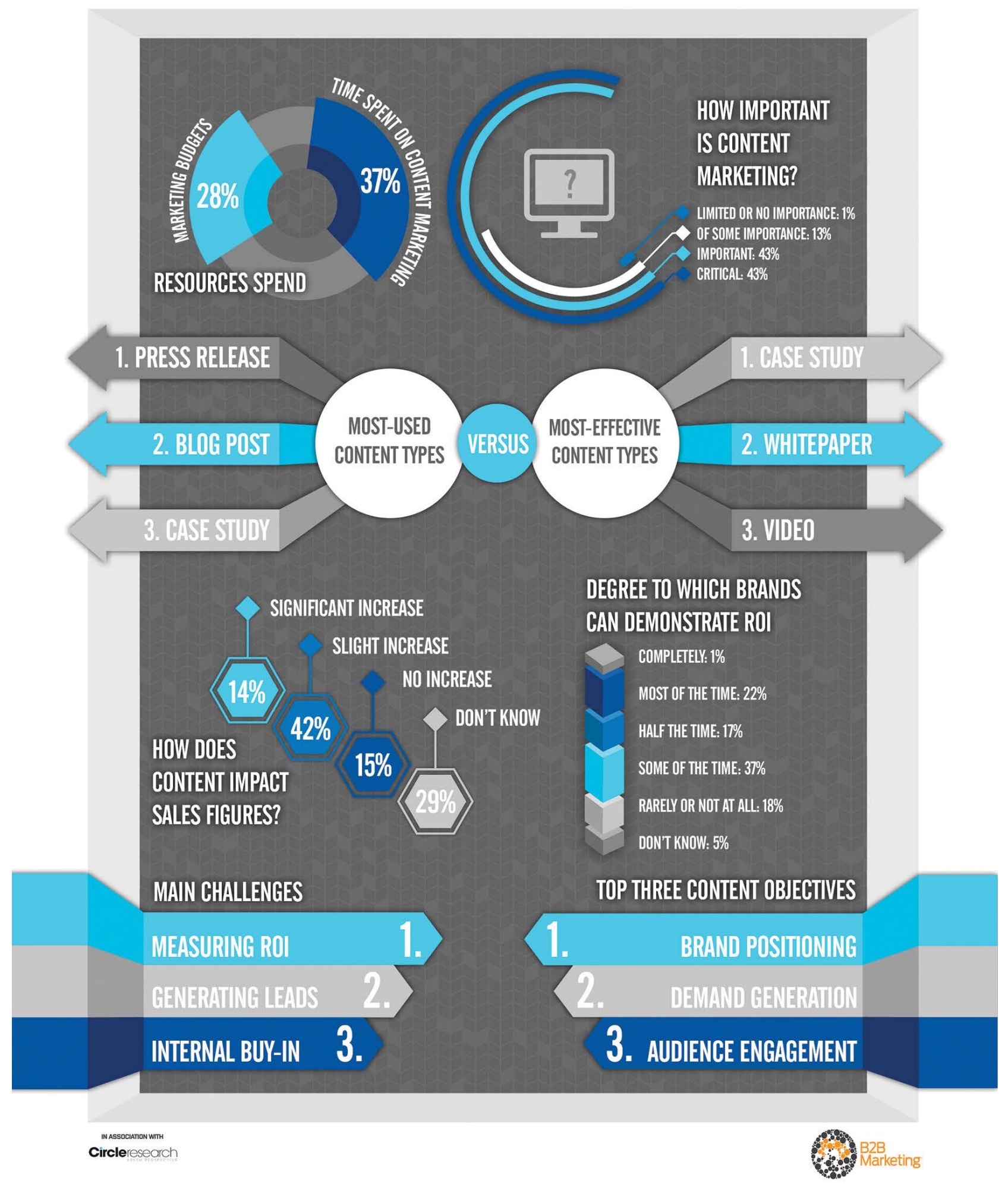

Figure 1. An infographic analyzing B2B's marketing between most-used content types and most-effective content types [13]. 


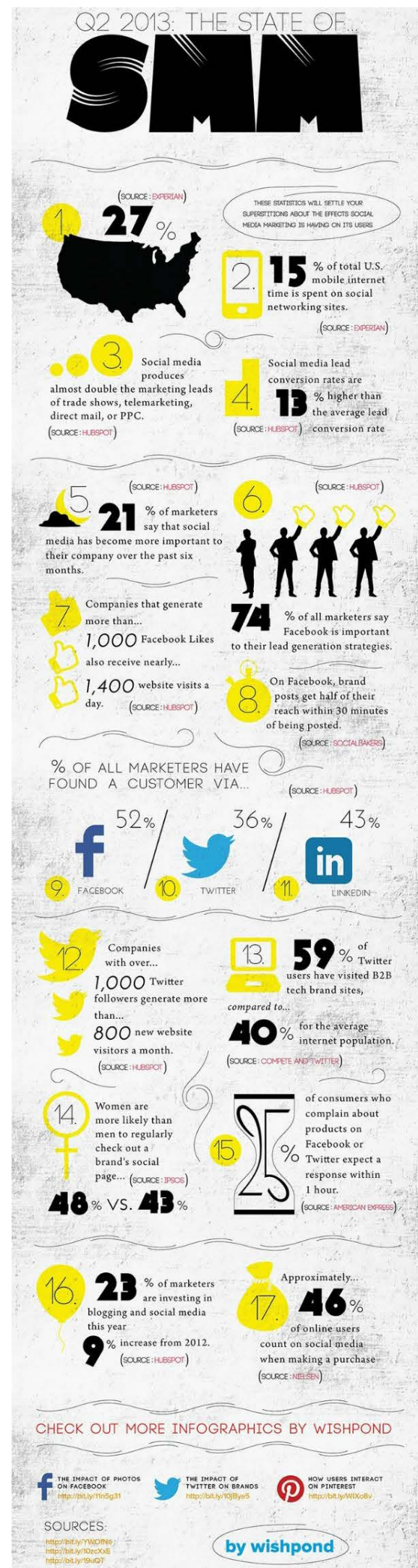

Figure 2. An infographic of the state of social media marketing [18]. about the prospect-not the firm.

As observed by Caragher [19], inbound marketing is more about pulling customers to the company and products, in a way that customers approach the company itself. Consequently, once content is created, it must be optimized for search engines and shared via social media. Search engine users overwhelmingly click on organic results on Google and Bing by a boundary of 94 percent to 6 percent.

\section{Marketing Point Of View: Inbound Marketing Vs Content Marketing}

According to Lieberman [21], inbound marketing is a broad, high level, descriptive term for marketing strategies that, instead of pushing interruptive messages out to clients, engage prospects and pull them in to the business. The goal of this methodology is to help prospects get to know, like and trust the company. In contrast, Lieberman [21] also stated that content marketing is an important part of inbound marketing. It is the same way a business company's website, email marketing, lead nurturing, video marketing, search engine optimization and other tactics are part of an integrated Marketing Machine. Meanwhile, Mann [22] stressed thatthe phrase "content marketing" has both more measured and broader connotations.

While comparing the definitions of both inbound and content marketing, it has been observed that both marketing methods are parallel. Isca [23] stated that both marketing methods differentiate are based on how and what they are being referred to. There are many different opinions and definitions towards the differences or similarities of content and inbound marketing; it is how they are being perceived.

From the marketing point of view, both content and inbound marketing are equally important and efficient towards promoting a smarter and better content for customers. Both are essential for e-commercialization and $\mathrm{m}$-commercialization with strong marketing tools.

\section{M-Commerce}

According to Abdullah et al. [24], m-commerce is a natural enhance version of e-commerce that allows users to interact with other users or businesses in a wireless mode wherever and whenever. Online shopping now also happens on post-pc devices such as smartphones, iPads or tablets. According to Aaron [25], it is also figure out that over one third of shoppers made minimum one purchase through smart device during the last 6 months. M-commerce was only $3 \%$ of e-commerce as on 2010 and at the end of last year's holiday, it has risen up to $11 \%$.

Kang and Kim [26] revealed the increased use of mobile communication and the swift growth in mobile 
shopping technologies have considerable financial potential, especially for business-to-consumer retail markets. Basically, m-commerce is one of the business transactions where price or essential terms were negotiated over an online system such as an Internet, Extranet, Electronic Data Interchange (EDI) network, or electronic mail system.

\section{Digital Content Marketing}

Rowley [27] introduced the concept of digital content marketing, or the marketing of products, in which both the entity and the delivery of the product are digital; such digital content is an increasingly important part of the commercial landscape (p. 518).

\section{Discussion}

As supposed by Google, Sullivan [28] noted that Hummingbird is paying more attention to each word in a query, ensuring that the whole query, the whole sentence or conversation or meaning is taken into account, rather than particular words. The goal is that pages matching the meaning do better, rather than pages matching only to a few words. Hummingbird only accommodates different ways that users search on Google. Looking ahead, Claburn [29] noted that Google can be expected to continue pushing the development of predictive search (Google Now) and voice search, because typing on a mobile device is slow and often impractical.

It is difficult to predict exactly what the future will entail, because Google is predictably unpredictable, but it is said to be safe that this update is a clear move towards a more Semantic Web, which aims at getting a better understanding of "aboutness" and not just from markup of entities, but in the ability to extract sentiment from the structure of a sentence. Henceforth, there is probably more coming. Egan [30] claimed that the answer is feasible in a more "implicit" search. Moreover, once users are on the Internet with their smartphones, 92.2 percent of users visit Google sites, followed by Facebook, at 84.6 percent; 83.2 percent visit Yahoo sites; and 68.6 percent go to Amazon sites. Vaughan-Nichols [31] claimed that this mirrors overall US Internet use, where Google, followed by Facebook, are the top two contenders.

\section{Conclusion}

Web searching, social networking, digital advertising or vice versa are somewhat the matter-of-fact routine or activity for the people living in this digital age. With more varieties of smart devices and web search engines, users are able to do their search online. Whether it is Google Panda, Google Penguin or Google Hummingbird, old or new algorithm, Google is consistently triggering and marking up new innovations and ideas with ad- vanced improvements and services to its consumers. With the new algorithm updated to such an advanced search, it allows searchers to easily retrieve the information or answers they want. My hypothesis was to find out Google's new algorithm, hummingbird's role in promoting content and inbound marketing, and also how its marketing strategy is arising as a new market idea. After collecting data, studying and finding the factors of Google's hummingbird, it is observed that Google has promoted the two marketing strategies. With the new algorithm providing an enhanced and smarter result, searchers will get to learn facts through web searching and gain more knowledge. This is a win-win situation for both marketers and customers. To achieve a better revolution, intelligence is a key factor. It is sure that Google is going to surprise us with any new interesting algorithms or applications. We notice that the pattern of web search has moved from typing to voice searching. Who knows - maybe the next algorithm for searching is brain scanning. With human intelligence, the future of technology will always remain unpredictable.

\section{REFERENCES}

[1] S. Balasubramanian, R. A. Peterson and S. L. Jarvenpaa, "Exploring the Implications of M-Commerce for Markets and Marketing," Journal of the Academy of Marketing Science, Vol. 30, No. 4, 2002, pp. 348-361. http://dx.doi.org/10.1177/009207002236910

[2] N. F. Awad and A. Ragowsky, "Establishing Trust in Electronic Commerce through Online Word of Mouth: An Examination across Genders," Journal of Management Information Systems, Vol. 24, No. 4, 2008, pp. 101121. http://dx.doi.org/10.2753/MIS0742-1222240404

[3] K. H. Lim, C. L. Sia, M. O. Lee and I. Benbasat, "Do I Trust You Online, and If So, Will I Buy? An Empirical Study of Two Trust-Building Strategies," Journal of Management Information Systems, Vol. 23, No. 2, 2006, pp. 233-266.

http://dx.doi.org/10.2753/MIS0742-1222230210

[4] P. B. Lowry, A. Vance, G. Moody, B. Beckman and A. Read, "Explaining and Predicting the Impact of Branding Alliances and Web Site Quality on Initial Consumer Trust of E-Commerce Web Sites," Journal of Management Information Systems, Vol. 24, No. 4, 2008, pp. 199-224. http://dx.doi.org/10.2753/MIS0742-1222240408

[5] O. Turel, Y. Yuan and C. E. Connelly, "In Justice We Trust: Predicting User Acceptance of E-Customer Services,” Journal of Management Information Systems, Vol. 24, No. 4, 2008, pp. 123-151. http://dx.doi.org/10.2753/MIS0742-1222240405

[6] D. Kim and I. Benbasat, "The Effects of Trust-Assuring Arguments on Consumer Trust in Internet Stores: Application of Toulmin's Model of Argumentation," Information Systems Research, Vol. 17, No. 3, 2006, pp. 286-300. http://dx.doi.org/10.1287/isre.1060.0093

[7] PR Newswire, "Internet Marketing Company Cyberset 
Adapts to Google’s New Algorithm, Hummingbird,” 2013. http://www.kusi.com/story/23758996/internet-marketing-com pany-cyberset-adapts-to-googles-new-algorithm-hummingbird

[8] J. Matthews, "What are Google’s Competitive Advantages?” 2012.

http://jasonmatthews.hubpages.com/hub/What-are-Googl es-Competative-Advantages

[9] J. Henshaw, "What Google’s Hummingbird Update Means for Content Marketers," 2013.

http://smallbusiness.yahoo.com/advisor/google-humming bird-means-content-marketers-143119302.html

[10] Jumpfactor, “Jumpfactor Provides Analysis of Google’s September 2013 'Hummingbird' Update with Content Marketing and SEO Content Perspective,” 2013. http://www.prweb.com/releases/2013/9/prweb11176534.h $\underline{\mathrm{tm}}$

[11] M. Laurel, "Reuteurn Light of Google’s Hummingbird Update, WebiMax Announces Importance of Mobile Content Strategy,” 2013.

http://www.reuters.com/article/2013/10/03/idUSnGNX22 WCwG+1cd+GNW20131003

[12] C. Rautenbach, "What Google Hummingbird Means for Online Marketing,” 2013.

http://www.bizcommunity.com/Article/196/423/101632.h $\underline{\mathrm{tml}}$

[13] A. Aspinall, "RESEARCH NEWS: Content marketing activities set for significant increase," 2013.

http://www.b2bmarketing.net/news/archive/research-new s-content-marketing-activities-set-significant-increase

[14] Content Marketing Institute, "What is Content Marketing?” 2013.

http://contentmarketinginstitute.com/what-is-content-mar keting/

[15] DeMers, “The Top 7 Marketing Trends That Will Dominate 2014,” 2013.

http://www.forbes.com/sites/jaysondemers/2013/09/17/th e-top-7-online-marketing-trends-that-will-dominate-2014/

[16] J. Pulizzi, "Marketing Trends 2013 for B2B Content Marketing,” 2012.

http://contentmarketinginstitute.com/2012/10/2013-b2b-c ontent-marketing-research/

[17] M. Brenner, “The Future Of Marketing E-Book,” 2013. http://www.b2bmarketinginsider.com/strategy/future-ofmarketing-ebook

[18] J. Iskandar, "17 Social Media Marketing Statistics You Need To Know,” 2012.

http://justiniskandar.com/17-social-media-marketing-stati stics-you-need-to-know/

[19] J. M. Caragher, "The Five Crucial Questions to Ask about Inbound Marketing,” CPA Practice Management Forum, October 2013.
[20] L. Kim, "What Is Inbound Marketing? The Story of How PPC Became 'In',” 2013.

http://www.wordstream.com/blog/ws/2013/05/29/what-is -inbound-marketing

[21] M. Lieberman, "The Difference between Content Marketing and Inbound Marketing,” 2013.

http://www.square2marketing.com/blog/bid/145625/TheDiffer-

ence-Between-Content-Marketing-and-Inbound-Marketin g\#sthash.x9fEcbk9.dpuf.

[22] R. Mann, "Smarter Content Marketing Versus Inbound Marketing,” 2013.

http://www.covario.com/2013/08/smarter-content-marketi ng-versus-inbound-marketing/\#fbid=MeICPoOatir

[23] F. Isca, "Inbound Marketing vs. Content Marketing: What's The Difference?” 2013.

http://smallbusiness.yahoo.com/advisor/inbound-marketin g-vs-content-marketing-difference-132548112.html

[24] H. H. Abdullah, A. M. Bohari, A. Warokka and A. Abdussal, "Strategic Role of Mobile Commerce (M-Commerce) Payment System: Establishing New Competitive Advantage,” Journal of Electronic Banking Systems, Vol. 2011, 2011, p. 1.

[25] M. Aaron, "Press Release Software: Emerging Trends of Mobile Commerce in 2013,” 2013.

http://www.whatech.com/members-news/software/15736emerging-trends-of-mobile-commerce-in-2013

[26] J.-Y. Kang and K. P. J. Kim, "M-Consumer Segmentation: M-Communication, M-Distribution, and M-Accessibility," International Journal of Marketing Studies, Vol. 5, No. 1, 2013, pp. 86-95.

[27] J. Rowley, "Understanding Digital Content Marketing," Journal of Marketing Management, Vol. 24, No. 5-6, 2008, pp. 517-540. http://dx.doi.org/10.1362/026725708X325977

[28] D. Sullivan, "FAQ: All about the New Google 'Hummingbird' Algorithm," 2013. http://searchengineland.com/google-hummingbird-17281 6

[29] T. Claburn, “Google Hummingbird Update, Explained,” 2013.

http://www.informationweek.com/internet/google/googlehummingbird-update-explained/240161885

[30] R. Egan, “3 Ways Content Will Be Affected by Google’s Latest Hummingbird Update,” 2013.

http://www.searchenginejournal.com/3-ways-content-will -affected-googles-latest-hummingbird-update/

[31] S. J. Vaughan-Nichols, “Apple IOS Gains on Google Android in Mobile OS Race,” 2013.

http://www.zdnet.com/apple-ios-gains-on-google-android -in-mobile-os-race-7000021611/ 